\title{
基底細胞母斑症候群に関する臨床病理学的検討
}

大屋高徳 -千葉 清 - 横田光正 - 石橋薰

柘植信夫・山口一成・近江啓一・工藤啓吾

藤岡幸雄・竹下信義*・佐藤方信*・鈴木鍾美*

\section{Clinicophathological investigation of multiple basal cell nevi syndrome}

\author{
Takanori Ohya - Kiyoshi Chiba - Mitsumasa Yokota - Kaoru Ishibashi \\ Nobuo Tsuge - Kazushige Yamaguchi $\cdot$ Keiichi Ohmi $\cdot$ Keigo Kudo \\ Yukio Fujioka - Nobuyoshi Takeshita* . Masanobu SatoH*. Atsumi Suzuki*
}

緒

言

1894年 Jarisch ${ }^{1}$ )が，基底細胞母斑症候群（以下 BCNS と略す）と思われる皮痛病変を初めて記載し，以後 Straith ${ }^{2)}$, Binkley and Johnson ${ }^{3)}$, Gross ${ }^{4}$, Gorlin and

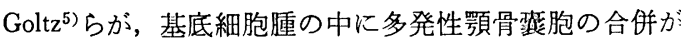
高頻度に認められることを報告した。ささらに Gorlin'6) は，

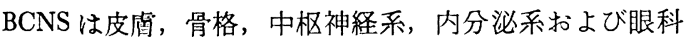
領域にも種々の異常を伴う症候群であることを明らかに した，以来，欧米では多数の報告がみられるようになっ たが，本邦では皮庭科領域に散見される程度で，口腔外 科領域に打いては大谷ら ${ }^{7)}$ ，原ら ${ }^{8)}$ の報告がみられるに すぎない そこで著者らは，これまでに本症候群を 4 例 経験しているので, これを臨床病理学的に検討し, 若干 の文献的考察を加えて報告する。

\section{症例}

検討対象とした症例は，1968年から1977年の10年間に 岩手医科大学荘学部第 1 口腔外科を受診し, BCNS と診 断された 4 症例である。

岩手医科大学崡学部口腔外科学第 1 講座（主任： 藤岡幸雄教授）

* 岩手医科大学菌学部口腔病理学講座（主任：鉿木 鍾美教授)

Department of Oral Surgery I, Iwate Medical University School of Dentistry (Chief: Prof. Yukio Fujioka)

* Department of Oral Pathology, Iwate Medical University School of Dentistry (Chief: Prof. Atsumi Suzuki)

受付日：昭和55年 6 月 10 日
症例 I：K. S. 59歳 男性 土木作業員.

現病歴： 1 年ほど前に，上唇中央部に小豆大の痂皮状 を呈する腫瘤に気付き，疼痛はなかったが増大する傾向 にあったために来院した

症例 II：S.S. 31藏 女性 主婦。

現病歴：2 力月前に $\overline{32}$ 部頓側根尖相当部の腫脹に気 付き来院。

症例 III : M. Y. 15歳 男性 学生.

現病歴：約 1 か月前に 1 8 部歯肉部の腫脹に気付き来 院.

症例 IV : F.O.11藏 男性 学生.

現病歴：下顎部のう蝕歯の治療のため約 1 か月前に某 幽科医を受診し,| 23 部歯肉の腫脹を指摘され当科を紹介 され来院した。

以下， 4 症例について種々検索した.

a . 家族歴

症例 I の子供（長男）に左側下顎角を中心に多房性の X線透過像か，また症例吕の母親に左側下顎角部に単房 性の, さらに症例 $I V$ 父親は両側下顎角部に多房性のX 線透過像がおのおのに認められた。 また，症例 II の子供 （女性） 2 人に左上唇裂が認められた。

\section{b. 既往歴}

症例 I は左脛骨骨折，また，症例 II は生後 3 か月に左 口唇裂の治療ならびに30歳の時, 卵巣䔶腫で手術を行っ た既往があるが，他の 2 例には特記するよらな事項はな い.

\section{c . 皮瘦における母斑の発生部位と局在性}

症例 I は, 胸部, 腹部, 背部に多数の母斑と両手掌に 多数の点状小窩および頸部の稗粒腫様皮疹が認められ た. 症例 II , III, IV も局在性に数個ないし数10個の母斑 と，手掌および足底部にも数10個の点状小窩を認めた。

\section{d. 顔貌と口腔内所見}

症例 I , II, II に前頭部突出, また症例 IV に後頭部の突 


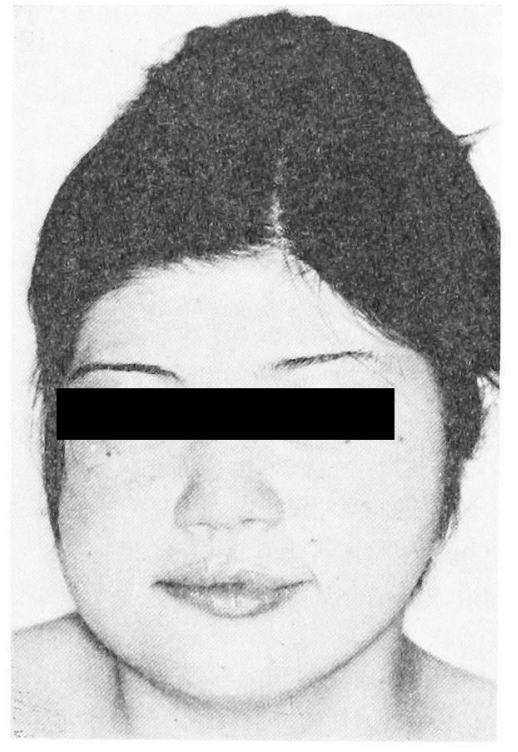

写真 1 症例 II の顔貌 丹斑が多数認められる。

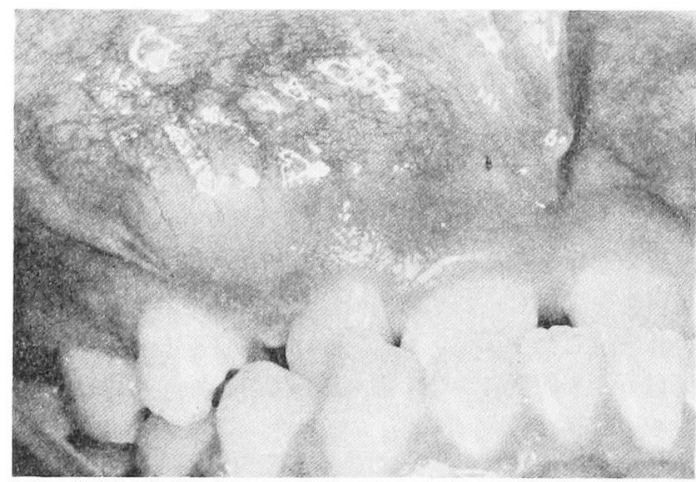

写直 2 症例 III口腔内所見

543| 部の歯肉の畽脤, 42| 齿牙の近遠心的移動および 下顎前突症を認める。

出がみられた，症例 II， III，IVに両眼隔離，そして症例 II，IIに軽度の下顎前突泟と幅の広い悬根を認めた。症 例 I は上口唇部の溃境形成が著明で，正中部が欠損し $\underline{2+2}$ の歯根が露出していた。 また濽湯部とその閣辺部 には多数の黑裩色の色素沈着がみられ，さらに左上眼瞼 には霞粒腫を認めた（写真 1)。そして症例 I は $2+2 の$ 口膑前庭部からこの米肉にかけて易出血性で，潰瘍の底 面は凹凸不正であった，他の 3 例はすべておのおのの瘇 脤した歯肉部および落肉煩移行部に比較的境界明瞭な腫 脹としてみられ，その表面の粘膜は正常でかつ一部羊皮 紙様感あるいは波動を触知できた。 また症例 II， II， IV において，覆胞に接する崡牙の近遠心あるいは煩舌的な

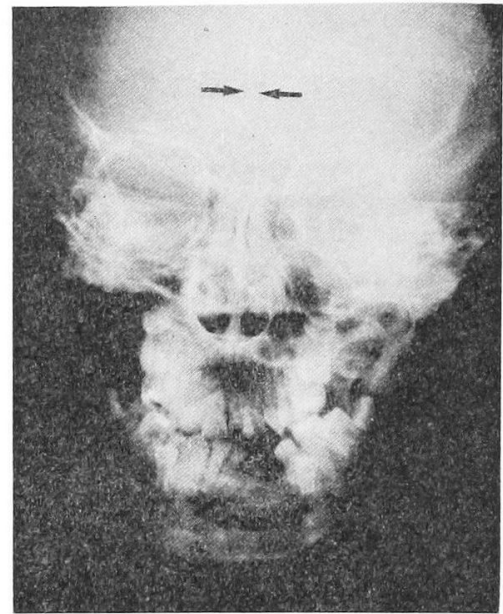

写真 3 症例 IV P P-A 頭部X線写真 大脳鐮の著明な石灰化像（矢印）を 認める。

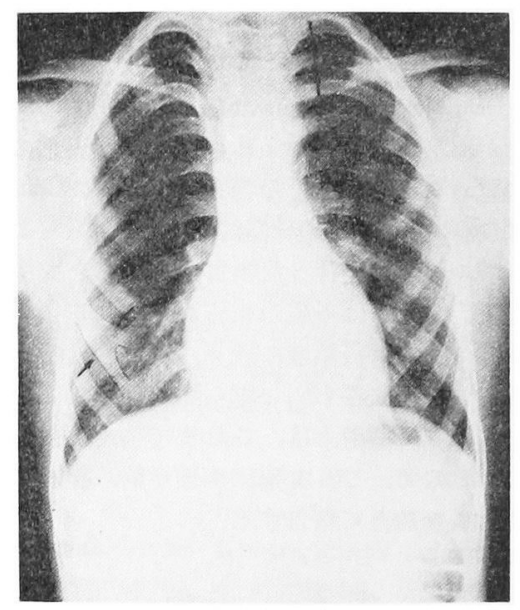

写直 4 症例 $N$ の眴部X線写真 二分肋骨と胁骨㙏合不全を認める.

圧排による移動がみられた（写真 2).

\section{e. $\mathbf{X}$ 線所見}

パノラマX線所見では，全例に多房性，多発性毫胞様 X線透過像と，その中に埋伏歯を認めた。 また症例 I

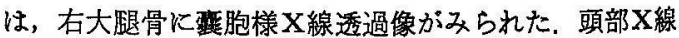
写真では全例に大脳鎌の石灰化像がみられ (写真 3)，ま た胸部X線写真では症例 I， II， NK二分胁骨を認め， また症例 Nの左第 2 肋骨に瘾合不全をみた (写真 4).

\section{f . 臨床検查成續}

全例とも血液一般, 血液化学, 尿一般, 尿化学検査な どで異常はみられなかった 


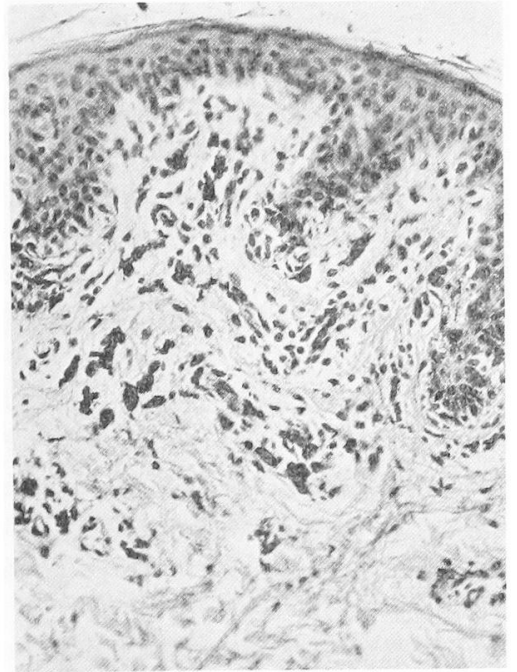

写真 5 症例 IIIの譄部皮膚にみられ た母斑の組織像

多数の母斑稩胞が結合部および真皮 内に認められる。

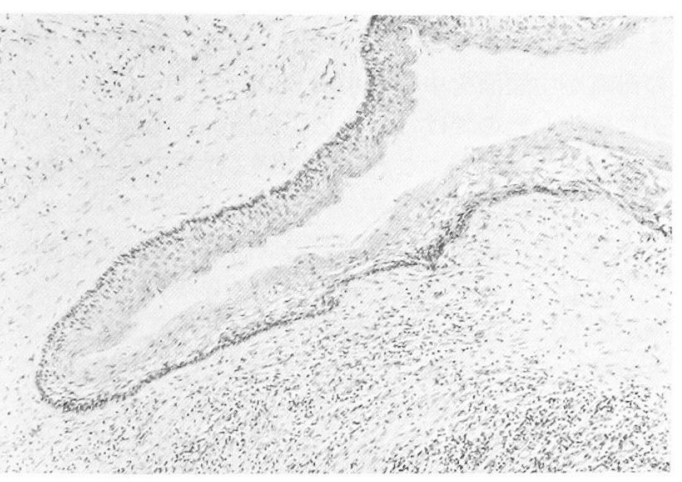

写真 6 症例 II の顎骨藤脃の組織像

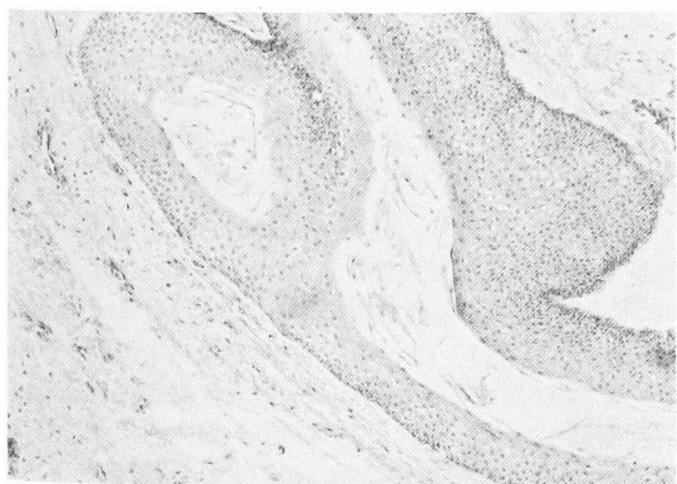

军直 7 症例 IV の顎骨落胞の組織像

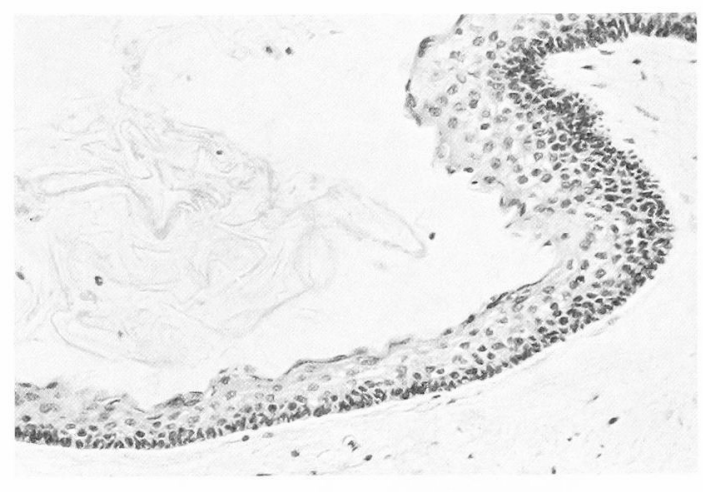

写真 8 症例 $\mathbb{I I}$ の顎骨薄胞の組織像

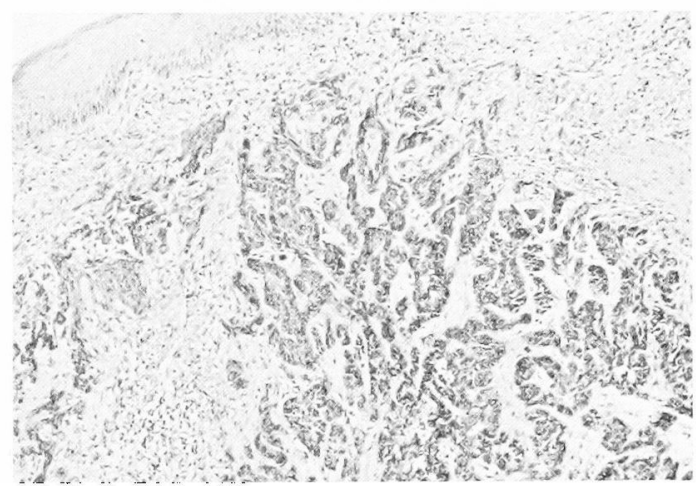

写真 9 症例 I の頓部皮下組織に浸潤增殖する基底 勫胞癌

\section{g. 病理組織学的所見}

著者らの症例の皮艒にみられた母斑は組織学的に母斑 細胞が結合部に存在するすの，あるいは真皮内に，また このいずれの部位にるみられるるのがあった。なお母斑 細胞のメラニン含量も症例により，ぬた部位によりさま ざまで，特に症例且の初診時に持ける胸部より採取した 母斑では（写真 5)，複合母斑の特徽を示していた，また

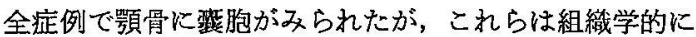
その壁は線維性の比較的厚い組織がらな，乙ばしば小 円形細胞のびまん性浸潤を伴って和り，その内面は角化 を伴ら重㬝扁平上皮により被覆され（写真 6，7），特に 症例 IIでは裂胞内に著明な角化物質を入れていた（写真 8．なお症例 I では，最初の入院から 2 年後に来院した 時に煩部より採取した標本で，上皮下に基底細胞癌の著 明な浸潤增殖があり，再発がみられた（写真 9）。

\section{h. 処置および経過}

症例 I は，上唇正中部の尰瘤部から生検を行い，その 結果 pigmented basal cell carcinoma であったので, ${ }^{60} \mathrm{Co}$ を $3,000 \mathrm{rad}$ 照射したところ, 上喜部の尰湯は消失

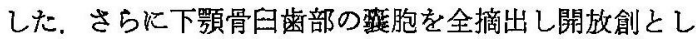
た.しかし，7か月後に再び上唇部から正中部上顎齿肉 


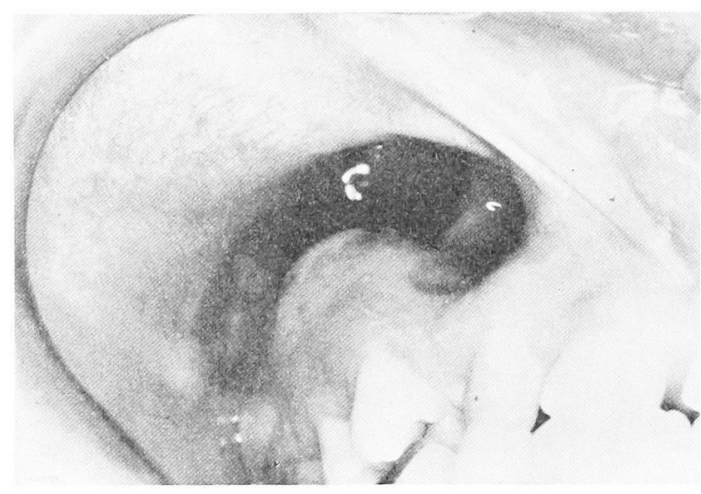

写直 10 症例 $\mathbb{I}$ の口腔内所見 薮胞全摘出術後の開故創

にかけて，腫凊の再発を繰り返したので (写真 9)，その 都度放射線治療と部分切除を施行したが，睡瘍の進展 は，下擷部，眼窩部そして煩部などへ払大浸潤し，初診 から 6 年後に全身転移して死亡した，症例 II，巡，Iは 祘の扣の右上顎，右上下顎，そして下顎正中部において 露胞を全摘出し，この部を開放創とした（写真 10). そ の後の経過は良好である。

\section{考察}

\section{1） BCNS の呼称とその歴史的背景}

本症候群は Clendenning ${ }^{9} か ゙ 1964$ 年に basal cell nevus syndrome と名付けてから一般化与るようになった。 そ のほか, nevoid basal cell carcinoma syndrome, multiple basal cell nevi syndrom ${ }^{9}$, multiple nevoid basal cell carcinoma syndrome ${ }^{10)}$, basal cell carcinoma syndrome'1), nevoid basal cell epithelioma syndrome, Gorlin - Goltz syndromes), hereditary cutaneomandibular polyoncosis ${ }^{12)}$, Fiinte phakomatosis BasalzellnevusKieferzysten-Syndrom (Ward Syndrom) ${ }^{13)}$, Epithelimatosen (Basaliomatosen) phakomatose などか同義語と して用いられている。

\section{2）人種別発生頻度}

本症䐅群は，一般に白人に多く黒人にはまれであると されている，そしてわれわれ日本人のような有色人種に おける発生においても少ないとされているが，当科では 最近の10年閏で 4 症例を経験した。今後, 本症候群の臨 床諸症状を知悉すれば，さらに本邦での BCNS の報告 例も增加するものとも考学られる。

\section{3）遗伝的関係と性差}

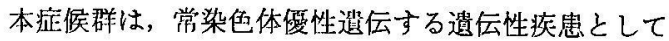
定着されてきている

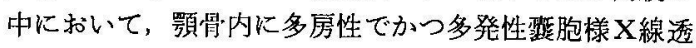
過像を認め，残る 1 例には，漞と子に唇裂が存在した。
このことは, 本症候群の遗伝的関連を強く示唆すること と考党る.

また性差においては，一般的に男女比はほぼ同程度に 発生するといわれているが，自験例は，少数例のために 比較することがむずかしいが，男 3 例，女1例の発生で あった。

\section{4) 臨床症状}

表 1 に示すGorlin ${ }^{15)}$ の分類した臨床症状を参考にして 検討した。

（1）皮凰症状：多発性基底細胞母斑，手掌および足蹼 の小䈑あるいは四肢の稗粒腫様皮瘆が主症状である。

i ）多発性基底細胞母斑：これは，わたくしどすの全 症例に出現したが, Gorlin'6)の報告にもみられるように， 思春期に出現しやすく，以後徐々に增加していると述へ ている．母斑は数個から多数のものまでがあり，その色 調は淡裼色から黒褐色を呈する平滑な丘淦あるいは小結 節として出現することが一般的である。すた全身の中で も，特に顔面や頸部，背部，腹部，胸部，上肢が䍜患 しやすく，中顔面部に出現することが多い(15)とする報 告もある．本症候群の基底細胞母斑は，镸期間表在性の 粦止した状態で，かつ侵襲性を欠く症例が多いが，Satoh $ら^{16)}$ の報告にみられるよらに，早期に癌化するものるあ る.また，わたくしどもの症例 Iでは，幼少時より多数 の母斑が中顔面を中心に出現し，この中で上唇部の母斑 から癌化したのではないかと現病歴から推察できた。

ii）掌踓小陷凹：これは掌蹽括よびその側縁あるいは 指趾背側部皮膚に多数みられる直径 1 〜 $3 \mathrm{~mm}$ の小陌迎 である. その成因は基底細胞の局所的な成熟過程の障害 によるものと考元られている17 19).このことより,これ ら小陥饥は，䧗床上本症候群の主要な診断的意義す有す る特徵的な所見である，通常は10藏以上より増踰に伴っ てこれが増加し，BCNS の50～60\%に本所見を認める. またまれに同部から基底細胞癌への移行がみられたとの 報告もある18,19)。したがって自験した 4 例にも手掌ある いは走底部に小陥凹が認められたので，母班と同様癌化 に対する十分な経過観察が必要であると考える。

iii）稗粒腫様皮疹：これは本症候群患者の約 $20 \%$ に認 められ，腫瘤は $1 \sim 2 \mathrm{~cm}$ で，顔面および四肢に好発す

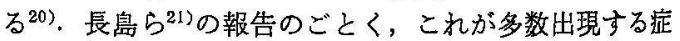
例もあるが，著者らの症例 I のごとく 1 個のこともある が，組蟣学的にはいずれも角質垔胞である.

(2) 顔貌 : 前頭部, 側頭 = 頭頂部の突出, 両眼隔離, 斜視，軽度の下顎前突症，幅広い奥根などがみられ， BCNS の一種独特な顔貌を呈する。自駼例では前頭部突 出が 3 例（症例 I， II， II ）, 両腿隔離が 3 例（症例 II， III, IV), 軽度の下顠前突症が 2 例 (症例 II, III), 幅広 い鼠根が2 例（症例I， III）に認められた。このことは 顔貌の所見が BCNS の診断にきわめて重要な所見であ ることを意味し，その他顔面に出現する母斑および顥骨 
表 1

multiple basal cell nevi syndrome (Corlin et al 1971)

\begin{tabular}{|c|c|c|c|c|c|}
\hline sign and synptom & $\begin{array}{l}\text { Relative } \\
\text { frequency }\end{array}$ & case I & case II & case 111 & casc II \\
\hline \multicolumn{6}{|l|}{ skin } \\
\hline \multicolumn{6}{|l|}{ 1)multiple nevoid basal cell carcinoma } \\
\hline with calcification, bone or osteoid & +++ & * & & & \\
\hline 2) palmar pits & ++ & * & * & * & * \\
\hline 3)milia;cysts, especially inks & ++ & * & * & * & * \\
\hline 4) comedones & + & & & * & * \\
\hline \multicolumn{6}{|l|}{ oral and facial manifestation } \\
\hline 1)multiple jal cysts & +++ & * & * & $\star$ & * \\
\hline 2)mild mandibular prognathism & +++ & & * & * & \\
\hline 3) fibrosarcoma of jan's & + & & & & \\
\hline 4) anelobl astoma & + & & & & \\
\hline \multicolumn{6}{|l|}{ skeletal system } \\
\hline $\begin{array}{l}\text { 1) ribs, bifurcation, splaying s!nostosis, } \\
\text { partial agenesis, or cervical } \\
\text { rudimentary }\end{array}$ & ++ & * & * & & * \\
\hline $\begin{array}{l}\text { 2) vertebrae, scoliosis, cervical or upper } \\
\text { thoracic fusion (lack of segmentation) }\end{array}$ & ++ & & & & \\
\hline 3)bridging of sella & ++ & & & & \\
\hline 4) frontal and temporoparictal bossing & ++ & * & * & * & \\
\hline $\begin{array}{l}\text { 5) spina bifida occulta (cervical or upper } \\
\text { thoracic or both) }\end{array}$ & \\
\hline 6) sindactyly, or ol igodactyly or both & + & & & & \\
\hline $\begin{array}{l}\text { 7) sprengel s deformity of scapla, medial } \\
\text { hooking }\end{array}$ & + & & & & \\
\hline $\begin{array}{l}\text { 8) shortened metacarpals (usually fourth } \\
\text { or fifth or both) }\end{array}$ & ++ & & & & \\
\hline 9)defective medial clavicle & + & & & & \\
\hline 10) pectus excavatum of carinatum & + & & & & \\
\hline 11) pes planus & + & & & & \\
\hline 12)hallux valgus & + & & & & \\
\hline \multicolumn{6}{|l|}{ central nervous system } \\
\hline $\begin{array}{l}\text { 1) mental reterdation, variable; } \\
\text { schizophrenia }\end{array}$ & + & & & & \\
\hline 2) congenital hydrocephalus & + & & & & \\
\hline $\begin{array}{l}\text { 3) calcification dura (falx, tentorium), } \\
\text { chroid, petroclinoid ligament }\end{array}$ & +++ & * & * & $\star$ & * \\
\hline 4) agenes is corpus callosum & + & & & & \\
\hline 5) medulloblastoma & + & & & & \\
\hline 6) nerve deafness & + & & & & \\
\hline \multicolumn{6}{|l|}{ eje } \\
\hline $\begin{array}{l}\text { 1) congenital blindness, coloboma } \\
\text { choroid and optic nerve }\end{array}$ & ++ & & & & \\
\hline 2)dystopia canthorum, hypertelorism & $+4+$ & & $\star$ & * & * \\
\hline 3) sunken appearance & + & & & & \\
\hline 4) chalazion & + & * & & & \\
\hline \multicolumn{6}{|l|}{ endocrine system } \\
\hline 1)pelvic calcification & + & & & & \\
\hline 2)ovarian fibroma, or cyst or both & +++ & & * & & \\
\hline \multicolumn{6}{|l|}{ 3)hypogonadisum, female pubic hair } \\
\hline $\begin{array}{l}\text { patter and scanty facial hair in } \\
\text { male pattems }\end{array}$ & ++ & & & & \\
\hline \multicolumn{6}{|l|}{ other findings } \\
\hline 1) inguinal hernia & + & & & & \\
\hline 2) 1ymphomesenteric cysts & ++ & & & & \\
\hline 3) kilncy mal formations & + & & & & \\
\hline
\end{tabular}

雚胞が認められると， 口䧑外科的に本症の診断も容易と なると考える。

（3）口腔症状：多発性靧骨䠝胞は BCNS の65７5\% 浔められ，本症の主要所見の1つである。本裂胞は多

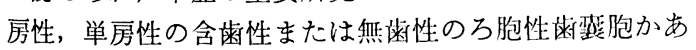
るいは歯原性角化㢣胞で, 10歳代に発現し約半数が顎骨

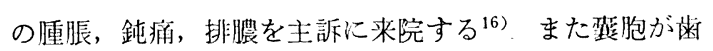
根形成期に出現すれば嫼胞に隣接する歯根の吸収, 彎 曲, 屈曲, 位置異常などを招来する，自験した 4 例の蕗 胞は, 病理組織学的に歯原性角化䔶胞であり, 症例 I は 口唇部溃瑒で他の 3 例はすべて幽肉の腫脹を主訴に受診 した。また裂胞に接する歯牙には根の異常は認められな 
かったが，権胞内に埋伏歯がすべての症例に認められた ことは, 興味ある所見であった。一方, 本症の蓃胞は土 ナメル上皮腫への移行 ${ }^{22)}$, あるいは再発しやすい22 24)な ぞの報告があるので，その処置にあたっては細心の注意 が必要である。自験の 4 例は, 嚄胞の全摘出を行い, 開 放創にした結果, 再発もなく良好な経過を認めている。

しかし症例 III若年者症例に開空療法を最初に試みたが 縮小傾向がなく，本症は開空療法が非楜応症とも考えら れるが，1例しか経験していないため今後の検討を待ち たい．また多発性顎骨整胞は，BCNS の主要所見である ので，この所見に遭遇した時は，一応本症候群も考える 必要があると思われる。

（4）骨格異常：骨格系の異常も，BCNS の60〜 75\%の 高頻度に認められる.すなわち二分肋骨あるいは splayed rib が最も多く発現し約 $40 \%$ である。次いで助骨の㾏合 あるいは発育不全の発現が多い16). しかし正常人にも二

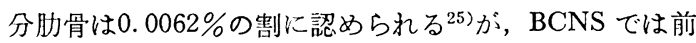
述のごとく，これが高頻度でみられることから，主要所 見の1つとしてあげられている。その他，脊柱変形が約 40\%，およびトルュ䩪の Bridging 像が約60\%の症例で 認められている26) さらに中手骨の短縮, 肩甲骨の異 常, 合指症, 多指症, クモ指症, 頸椎・胸骨の癒着, 長

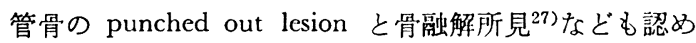
られる。自験 4 例では 3 例（症例 I, II，IV) に二分助 骨, 1 例 (症例IV) に肋骨嘴合不全, そして 1 例（症例 I ）に大腿骨の punched out lesion がX線写真で確認 された。このことは症例 I の既往に, 大腿骨骨折がみら れたのと何らかの関連性があるものと考えられる。

（5）中枢神経系: 精神薄弱, 精神分裂症のほか, 頭頂 部，鉡部，天幕部，脈絡膜部などに層板状の石灭化がし ばしばみられる。しかし，頭部石灰化罢常は，正常人で も約 $8 \%$ の割でX線的に認められ，さらに加秢的に增強 するという報告もある ${ }^{28)}$ 。しかし BCNS でみられる石 灰化像は, 独特な幅広い像を呈し, かつ幼年者の症例に も認められることが特徵である。自験例においては, 全 例に大脳鏣の石灰化像が観察され，特に症例 III， IVのよ うな若年者においてもこの所見を訫めた。その他に，解 芽細胞腫の合併症も報告されている ${ }^{29)}$ が，自験例ではな かった。

（6）腿病変：これには角膜混濁, 白内障, 緑内障, 脈 絡膜・視神経久損による先天性盲目，雨眼隔離などが報 告されている。自験 4 例では 3 例（症例 II, II , IV) に 雨眼隔滩， 1 例（症例 I ）に霰粒腫が認められた。

（7）内分泌系症状: Gorlin 5 ${ }^{29}$ は短手骨あるいは種々 の骨格系の石灰化異常はカルシウムとリンの異常な排出 によるものであると述べている。また Clendenning(15)は parathormone に対する感受性の低下による仮性副甲状 腺機能低下症を強調しているが，近年は否定的な見解が

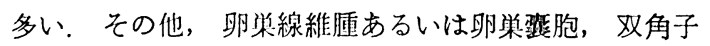

宮, 男性の性機能不全症があげられる. 自験 4 例では 1 例（症例 II）にだけ卵紧翟胞症の既往があった。

（8）その他の症状：腸間膜の lymphatic cyst, 鼠径部 ヘルニア, 腎臓の奇形, 鬼唇などが報告されている。自 験例では 1 例（症例 II）に鬼居の既往がみられた。

\section{5）成因}

本症の成因はいまだ不明な点が多いが，川村年はは，多 種多様の母斑性病変が全身性間葉系組織の遺伝子レベル の暴常に由来するものと考え，またさらに種々な上皮性 組織の病変も異常な結合組織によって誘導された結果生 ずると推察している。しかし今後, 逭伝子レベルからの 検索が是非とも必要であると考える。

\section{結語}

わたくしどもは，1968年から1977年までの10年間で 4 症例の基底細胞母玟症候群を経験し，これを臨床病理学 的に検討した。 そして若干の文献的考察を加えて報告し た。

\section{引用 文 献}

1) Jarisch, A.: Zur Lehre von den Hautgeschwülsten. Arch Derm Syph 28: 1631894.

2) Straith, F.E.: Hereditary epidermoid cyst of jow. Am J Orthodontics \& Oral Surg 25: 673 1939.

3) Binkley, G.W., Johnson, H.H., Jr.: Epithelioma adenoides cystcum: Basal cell nevi, Agenesis of corpus callosum and dental cyst. Arch Dermat \& Syph 63: 731951.

4) Gross, P.P.: Epithelioma adenoides cysticum with follicular cyst of maxilla and mandible. J Oral Surg 11: 1601960.

5) Gorlin, R.J., Goltz, R.W.: Multiple nevoid basal-cell epithelioma, jaw cysts and bifid rib; Syndrome. New England J Med 262: 908 1960.

6) Gorlin, R.J., et al.: The multiple basal-cell nevi syndrome. An analysis of syndrome consisting of multiple nevoid basal cell carcinoma, jaw cyst, skeletal anomalies, medulloblastoma and hyporesponsiveness to parathormone. Cancer 18: 891965.

7）大谷隆俊，他：基底和胞四斑症候群と思われる 1 例。日口外誌 22：723 1976 .

8）原雪江，他：基底細胞母:斑症候群の 1 例。 日 口外誌 24: 5651978.

9) Clendenning, W.E., et al.: Basal cell nevus syndrome. Arch Derm 90: 381964.

10) McEvoy, B.F., Gotze, K.H.: Multiple nevoid basal cell carcinoma syndrome. Radiologic manifestations. Brit J Radiol 42: 241969. 
11) Ferrier, P.E., Hinrichs, W.L.: Basal cell carcinoma syndrome. Amer J Dis Child 113: 538 1967.

12) Pollard, J, J., New, P.F. J.: Hereditary cutaneomandibular polyoncosis. A syndrome of myriad basal cell nevi of skin, mandibular cysts, and inconstant skeletal anomalies. Radiology 82: 8401964.

13) Tobias, C.: Zum Basalzellnevus-Kieferzysten Syndrome (Ward Syndrome) mit familiaren Auftreten. Schweiz med Wschr 97: 9491967.

14) Clendenning, W.E.: Clinical Dermatology, Vol 4 unit 21-20. ed 1, Harper and Row. Hagerstown, 1972.

15) Gorlin, R.J., Sedano, H.O.: The multiple nevoid basal cell carcinoma syndrome revisited. Birth Defects Original Article-Series 7: 140 1971.

16) Satoh, M., et al.: Two cases of nevoid basal cell cartinoma syndrome. Acta Path Jap 27: 7131977.

17) Pollizer, J.: Eine eigentumliche Karzinose der Haut (carcinoderma pigmentosum-Lang) nebenher: Punkt-und strishformige Defect im Hornstatum der Palmae und Plantae. Arch Derm Syph 76: 3231905.

18) Howell, J.B., Mehregan, A.: A story of pit. Arch Derm 102: 5831970.

19) Howell, J.B., Mehregan, A: Pursuit of the pit in the nevoid basal cell carcinoma syndrome.
Arch Derm 102: 5861970.

20) Hermans, E. J., et al.: Eine funte Phakomatosis; Naevus epitheliomatodes multiplex. Hautarzt: 11: 1601960.

21）長島正治，他：基底細胞母斑症候群。臨皮 28 : 271974.

22) Toma, K.H., et al.: Polycystoma. Oral Surg 12: 4841959.

23）榎本昭二, 他：原始性乘胞 (primordial cyst) の 臨床的研究。日口外誌 23：121 1977.

24) Browne, R.M.: The odontogenic keratocyst; Histological feature and their correlation with clinical behavior. Br Dent J 131: 2491971.

25) Etter, L.E.: Osseous abnomalities of thoracic cage seen in 40, 000 consecutive chest roentgenograms. Amer J Roentogenol 51: 3591944.

26）6）より引用.

27）池田重雄，他：基底細胞母斑症候群。日本臨床 35：784 1977 上り引用.

28) Herzberg, J, J., Wiskemann, A.: Die funte Phakomatose, Basalzellnaevus mit familiarer Belastung und Medulloblastom. Dermatologica 126: 1061963.

29) Gorlin, R.J., et al.: Multiple nevoid basal-cell carcinoma, odontogenic keratocyst, and skeletal anomalies syndrome. Acta derm-venereol 43: 391963.

30）川村太郎：好琣細胞の起源と母斑症の病理発生 (2)。皮湆臨床 19：325 1977 . 